\title{
COMPARING TURKISH-SPEAKING RAP SCENES IN \\ GERMANY AND THE NETHERLANDS
}

Almanya ve Hollanda'daki Türkçe Rap Sahnelerinin Karşılaştırılması

Tunca ARICAN*

\begin{abstract}
The main purpose of this article is to explore to which degree socio-political differences between Germany and the Netherlands particularly from early 1980s to late 90's, where the Turkish population has a high density, affect developments of the Turkish-speaking rap music scenes in early 2000s. Here, the basic question is why Germany generally comes to mind when many people think of Turkish-rap music, but the Netherlands does not. To answer this question, I basically examined to what extent political (particularly as regards migration policies) and social conditions in the two countries have influenced the development of Turkish-language rap music. Cultural and political differences between these two countries and also the attitudes of the host society towards foreigners have led the Turkish rap scene in the Netherlands to remain less "developed" than that of Germany.
\end{abstract}

Keywords: Turkish Rap Scenes, Exclusionist Policies, Multiculturalism, Citizenship, Germany, Netherlands.

\section{ÖZ}

Bu makalenin temel amac1, Türk nüfus yoğunluğunun yüksek olduğu Almanya ve Hollanda arasındaki, özellikle 1980'lerin başlarından 1990'ların sonlarına kadar etkisini gösteren sosyo-politik farklılıkların, Türkçe Rap Müziği’nin erken dönemlerinde gelişimini nasıl etkilediğini tartışmak olacaktır. Buradaki temel sorular, Türkçe Rap Müziği denildiğinde ilk akla gelen ülkenin neden Almanya olduğu, Hollanda'nın ise akla neden gelmediğidir. Bunun hangi etkenlerin sonucu olduğu somut farklılıklar aracılığıyla gösterilmeye çalışılacaktır. $\mathrm{Bu}$ iki ülke arasındaki kültürel ve politik farklılıklar, ev sahibi toplumların yabancılara karşı tutumu, Hollanda'daki Türkçe-Rap sahnesinin Almanya'dan daha az "gelişmiş" kalmasına mı neden olmuştur.

Anahtar Kelimeler: Türkçe Rap Sahneleri, Çokkültürlülük, Dışlayıcı Politikalar, Vatandaşlık, Almanya, Hollanda

\footnotetext{
* Araştırma Makalesi - Geliş Tarihi/Received Date: 30.04.2019 Kabul Tarihi/Accepted Date: 28.05.2019

* Sorumlu Yazar/Corresponding Author: Hacettepe Ankara Devlet Konservatuvarı Müzikoloji Bölümü. tuncaarican@gmail.com. ORCID No: 0000-0003-4569-3253

Atıf/Citation: Arıcan, T. (2019) Comparing Turkish-Speaking Rap Scenes In Germany and The Netherlands. Eurasian Journal of Music and Dance, (14), 203-213.
} 
According to Deleuze and Guattari, “[c]ivilized modern societies are defined by processes of decoding and deterritorialization. But what they deterritorialize with one hand, they reterritorialize with the other" (Deleuze and Guattari 1990, p. 257; italics in original). This simply means that deterritorialization, as a consequence of globalization (Kearney, 1995), refers not just to dissolution of the connection between space and culture and of territorial boundaries, but also localization, transnational relations or reterritorialization of those which are not located in a particular site anymore. Cultural flows between global and local have become mutually effective in this sense (Appadurai, 2000). That is to say, any community in various geographies would benefit from particular cultural products, such as hip-hop culture, as a way to connect both with the globe and their own local boundaries, including visible strategies regarding their own consumption and production. In this sense, cultural globalization does not refer to homogenization of cultures, but rather to the connections between local and global in terms of compression of time and space. According to this, "[...] one of the effects of the process of globalization has been to make us aware that the world itself is a locality, a singular place" (Featherstone, 1997, p. 92) in which exchanges of cultural products globally are constantly increasing. Nevertheless, what is striking here, and requires awareness, is that cultural globalization is a concept which could be understood more effectively through deterritorialization, which is "the loss of the 'natural' relation of culture to geographical and social territories", as Tomlinson states (quoted in el-Ojeili and Hayden, 2006, p. 134). In this process, new identities emerge or are eroded locally in terms of the encounter between West and East in a positive or negative manner. In this context, the local is basically not 'fixed' but a "contested territory" "that is crossed by different forms of collective life and the competing sensibilities that the latter bring to bear on the interpretation and social realization of a particular place (Bennett, 2000, p. 53) ". Recent discussions of this condition of interrelatedness led to the emergence of another mixed concept called "glocalization", a sociological term developed by the sociologist Roland Robertson in the 1990s in order to examine particularities and localities in universalizing globality (Robertson, 1995). According to Ritzer, the term "can be defined as the interpenetration of the global and the local, resulting in unique outcomes in different geographic areas (Ritzer, 2003, p. 193)". While these "unique outcomes" kept many researchers studying subjects ranging from culture to ethnography, a new cultural pattern was about to appear. For instance, German-Turkish rappers tend to use hip-hop as a way to connect with the globalized "hip-hop nation", while localizing it with their own musical, cultural and linguistic contributions, such as oriental music or ethnic perceptions, whether intensively connected with other scenes or not. For example, although best known Turkish rap band "Cartel's use of the label 'Oriental' and the political language of hip-hop brought a heightened discussion of the Turkish minority into the media (Diessel, 2001, p. 176)", "the group Islamic Force [...] is commonly recognized as the spark that started Oriental hip-hop (Diessel, 2001, p. 169)". In their recordings, the band sampled songs written or performed by prominent Turkish musicians such as Barış Manço, Sezen Aksu, İbrahim Tatlıses, Erkin Koray, etc ${ }^{1}$. Boe B. from Islamic Force says the following about their original genre,

We do it in Germany, originating from Turkey and using an American black style of music and Turkish melodies [...] The boy comes home and listens to hip hop. The[n] his father comes along saying: "Come on boy, we go shopping", enters the car and listens to Turkish music. And then he acquires our record and gets both styles in one (Elflein, 1998, p. 263).

\footnotetext{
${ }^{1}$ For detailed information of sample database, it can be look at https://www.whosampled.com/Islamic-Force. (Accessed May. 2019)
} 
The story of Turkish rap began "in the late 1980s in the transnational meeting of two mobile groups of people: African-American soldiers stationed in Germany during the waning days of the Cold War and the period immediately after its end, and second-generation Turks in Germany, the children of economic migrants (Solomon 2009, p. 307)". The first recorded rap song in Turkish, Bir Yabancinin Hayatı ("The Life of a Stranger') by the Nuremberg crew King Size Terror, was released in 1991. Particularly in the 1990s, a wave of racist and xenophobic violence occurred in Germany. The song is about discrimination, racism and difficulties that immigrants intensively experience in Germany. For instance, a Turkish woman and four of her children died in an arson attack set by four skinheads on their family home in Solingen in May 1993. In the aftermath of this tragic event in 1995, German-Turkish rap group Cartel released an album that accelerated the development of rap music among Turkish immigrants as a means of voicing their reactions against racism. Moreover, the album gained a significant commercial success in both Germany and Turkey as well.

The story of Turkish rap in the Netherlands began in the mid-nineties with Şener-E (Dutch-born), who was regarded as the first musician rapping in Turkish and a seminal figure of the scene as well. Like most Turkish rappers living both in Turkey and abroad, his enthusiasm for rap music came through Cartel. In the first songs he produced during the 1990s, he incorporates local cultural and political insights by Dutch-Turks via using Turkish language for the song lyrics. For example, the song titled "Deprem" ("Earthquake") ${ }^{2}$ by Dutch-Turkish rapper Şener-E, draws attention to the synthesis of Turkish musical idioms, melodies and language. This song apparently follows the precedent set by Cartel in the mid-1990s for the "Oriental rap music" in which Turkish folk music samples are used. this song also points out "[ $[.$.$] how the musicians hybridize the genre of rap music$ with Turkish folk music, using Turkish musical instruments and Turkish melodies in songs with rapping and hiphop style beats (Solomon, 2007)". The song starts off with a melody played with bağlama (traditional lute instrument) repeated a few times and then a synthesizer, the preset of which is a human voice playing somewhat a sad melody. During the song DJ-style scratching is used, here apparently produced by computer.

What he strives for is to illustrate how Turkish migrants are overcome by the liberal socio-cultural structure in the Netherlands comparatively to many EU countries particularly in those years. In this context, the main purpose of this article is to investigate to what degree socio-political differences between Germany and the Netherlands affect developments of the Turkish-speaking rap music scenes in the two countries. As Turino (2003) argues, in order to grasp the discrimination that different ethnic groups are subjected to in their hostsociety or the specific difficulties they suffer from because of their ethnic origins, we need to examine that country's legal substructures, immigration laws, citizenship policy, religious tolerance, etc. To examine this issue, I will basically examine to what extent political (particularly as regarding migration policies) and social conditions in the two countries particularly from early 1980s to late 90's have influenced the development of Turkish-language rap music.

This article derives from my doctoral dissertation, completed in 2011 after ten months in the field in the Netherlands and Germany between 2006/07. During the period that I stayed in the Netherlands, I carried out face-to-face and in-depth interviews with twenty seven Turkish rappers. The short representative samples

\footnotetext{
${ }^{2}$ On August 17, 1999 at 3:02 AM, an earthquake of magnitude Md 7.4, which was one of the most devastating earthquakes of the twentieth century in terms of the number of casualties and huge damage, occurred in the Kocaeli area in Northwest Turkey, which has a population of 20 million inhabitants. The estimated death toll is as high as 40,000. Şener-E's song is about this major disaster.
} 
discussed here are thus drawn from a far broader pool, but are intended to be representative, and illustrative of the article's main premises.

\section{Socio-Political Differences between Germany and the Netherlands}

The Netherlands, known as a country of minorities, suffered from Protestant-Catholic tension for a long period. The Dutch state has much experience with diverse religious and ethnic groups existing in the country. Indeed, these past attempts of the Netherlands to face minority problems and to solve them politically have provided it with a different perspective on contemporary problems. In a stable and peaceful way, the Netherlands tried to solve possible clashes among those groups. In this context, "the Dutch pillarised variant" becomes much more important, since it seems to form a background of multiculturalism that "allows for relatively great recognition of cultural difference and grants religious identities much visibility in public life" (Saharso, 2007, p. 527)". Apparently, the experience of the pillarized structure of Dutch society has kept the government from acting through assimilationist policies (see Penninx, 1996).

The immigration policies of the Netherlands, practiced since the 1960s, have apparently changed every decade. In the seventies, the Dutch government shifted its policies on guest workers, who seemed not temporary any more, but required the government to make particular policies in order to enable their participation in the host society with equal rights. In 1983 the Dutch government ${ }^{3}$ officially stated that the Netherlands was a multicultural society and proposed a "two-track minorities policy, aiming at the integration as well as the preservation of cultural identity" (Eldering, 1997, p. 334). This means that immigrants could conserve their own language and culture under the protection of the government. It seems that the practicing of such policies was the beginning of multiculturalism in the Netherlands. In the 1990s, in the Netherlands,

a new discourse emerged in which members of ethnic minorities were less considered as cultural/religious groups and more as individuals. While it was still conceded that minorities should have the opportunity to foster their own (cultural and religious) institutions, more stress was put on integration (Uitermark et al., 2005, p. 627).

With that discourse, new social perceptions, based upon a sort of distance felt against the host society, by Dutch-Turks appeared. What I mean could be much more visible the words by a Dutch-Turkish rapper from Amsterdam, Şaperon,

I've experienced this [having two identities]. For example, I saw that the Turkish and Dutch people aren't close to each other here. Turks make up 90 percent of the population in the neighborhood we live in. We don't live very close to Dutch people. We know nothing about their culture. I said that we've lived here for 40 years, but as Dutch-Turks, not just Turks. We're Dutch-Turks or Turks living in this Netherlands ${ }^{4}$.

Basically, what he points out that many of them do not show neither any fear against nor "sympathy" for the host society. Therefore, what they feel about the Dutch culture is to be "compartmentalized" by the host

\footnotetext{
3 "In its 1983 Minorities Memorandum, the Dutch government recognised that 'in many ways our country has been given a different face after the Second World War ...Therefore conditions must be created by the minorities policy to realize the equivalence and equal opportunities of all residents"” (Vink, 2007: 340).

${ }^{4}$ The interview was conducted in 2007.
} 
society. Moreover, the main reason behind the comparatively "peaceful" environment of the Netherlands for foreigners seems that the Netherlands, unlike Germany, had conceived of itself as a country of immigration. It looks that such a socio-political environment has made Dutch-Turkish youngsters feel relatively "safer" than their counterparts in Germany.

Unlike the Netherlands, Germany's “exclusionist” (see Kaya, 2001) practices have forced Turkish immigrants to construct an isolated Turkish community and a cultural-political space for themselves. The particular reason for these exclusionist policies of the state is that "Germany's 'foreigner policy' (Ausländerpolitik), was until recently strongly shaped by an ethno-cultural notion of national identity and citizenship (Koopmans and Statham, 2001, p. 73)". Ayhan Kaya (1998, p. 28) divides Germany's Ausländerpolitik into three stages: "The main concern of the first stage of the Ausländerpolitik between 19651973 was economic considerations. The second stage of the law was shaped by concerns of increasing social problems and political tensions". The third stage began with the Christian Democratic Party (CDU). In this stage, the government

restricted the entry of further immigrants, spouses and dependent children of immigrants by applying new quotas... [Moreover] the government encouraged repatriation with a decree between October 30, 1983 and June 30, 1984 by offering premiums of DM 10,500 plus DM 1,500 per dependent child if they left the country immediately (Kaya, 1998, p. 29).

We see here that during the 1980s and 1990s, Germany's Ausländerpolitik was actually put into practice to encourage guest workers to return to their home countries by offering them cash payments and setting up bilingual schools ${ }^{5}$ in their home countries to help German-speaking migrant children re-adjust to life "back home" (see Kaya, 1998). Ayhan Kaya states that in the 1960s and early 1970s, with the Foreigners Law, the German state "established a system of 'institutional discrimination', through which temporary workers could be recruited, controlled and sent away, 'as the interests of capital dictated' " (Kaya, 1998, p. 28).

It seems that Germany's "exclusionist" model has caused "fear" among Turkish migrants that their culture is being eroded. Moreover, Germany's lack of interest in integrating its "guest workers" into German society, and the resulting ghettoization of them (i.e., in communities like Kreuzberg) has historically actually resulted in their being able to maintain their culture. If we consider the fact that Turkish immigrants have been subjected to social exclusion and have had to deal with direct racist attacks in their everyday life, then their lack of connection to German society, compounding isolation, and the reasons behind the fact that they have not established German identity become much more understandable. German journalist and ethnomusicologist Martin Greve explains this by saying, "It is clear that immigrants' experiences with broad discrimination, exclusion and obvious xenophobia have prevented immigrants from constructing German identity (2006, p. 71)”. There is no doubt that "[d]iscrimination presents a threat to group identity, making people increasingly turn toward the minority ingroup (Verkuyten and Yildiz 2007, p. 1449)". In this context, it could be better to describe under which conditions Turkish rap music appeared in Germany and to what extent violent attacks against foreigners took place in that period.

\footnotetext{
5 "The schools are called Alman Anadolu Lisesi (German Anatolian High School) where the medium of education is German. These schools are formed under the joint Cultural Treaty signed between Turkish and German government in 1984” (Kaya, 1998, p. 30).
} 
Due to the brutal attacks on foreigners and their belongings during the years of xenophobia in Germany in the 1990s, rap music has become a kind of political tool which was used by German-Turkish young people against racism and far-right political ideologies. The main reason for the rising popularity of rap music among Turkish youngsters is the success of the German-Turkish rap group Cartel with its anti-racist and political lyrics, which had a significant impact on the hip-hop scene of German-Turks. Germany has become the homeland of Turkish rap and has particular socio-political particularities which have been effective in the appearance of the genre (see Çağlar, 1998; Elflein, 1998; Diessel, 2001; Kaya, 2001). On the other hand, Dutch-Turkish rappers usually talk of a kind of cultural "isolation" and feeling like not to belong both Dutch and Turkish social sphere instead of expressing to face with violence or brutality. For instance, Beatbox Sefa (21), who has been living in the Netherlands for 5 years, explains this distinction as follows:

We grew up in Turkey and conversed with Turkish people. Because everybody is a Turk, everybody knows each other's origin. Nevertheless, those who were born here do not learn family culture. Why do they not have it? This guy was born here... He does not know family culture. As I said, you know Turkish people. You were also born and grew up in Turkey. In Turkey even if you are in a market to buy something, you can easily start a conversation. It might be a small talk but you enjoy this chat. It is not the same here.

\section{Differences between the Dutch and German-Turkish Rap Scenes}

Simon Frith states that "our feelings about a piece of music are, of course, drawn by the music: we listen, we respond. But we listen on the basis of who we are and what we musically know and expect, and we respond according to who and where and why we're listening" (Frith, 2004, p. 33). Frith therefore argues that "musical judgments are also ethical judgments". Moreover, for him, the aesthetics of music "involve a particular mix of individualism and sociability $(2004$, p. 33)"

Social and political connections between cultural products, such as local music scenes or youth life styles, enable us to elaborate historical background of those scenes or styles. The lack of focus on peculiar sociopolitical structures in host country for local music scenes could be insufficient for elaborate those scenes. In this sense, while some of academic works on local music scenes,

generally focus on specific urban location with particularized local sensibilities of the city and the state,

[...] much recent work on local music scenes is less concerned with 'organic' relationships between music and the cultural history of the locale than with the ways in which emergent scenes use music appropriated via global flows and networks to construct narratives of the local (Peterson and Bennett, 2004, p. 7).

In this context, to which extent Turkish-speaking rap music has become local, transnational or to develop as a virtual scene become important question to elaborate why German-Turkish scene is relatively "coherent" than its counterpart in the Netherlands. For this question, I will benefit from Peterson and Bennett's three types of scenes definitions. First, local scene, "corresponds most closely with the original notion of a scene as clustered around a specific geographic focus (Peterson and Bennett, 2004, p. 6)". Secondly, translocal scenes refer to a sort of 
interaction of local scenes in distant places that "while they are local, they are also connected with groups of kindred spirits many miles away (Peterson and Bennett, 2004, p. 8)". Petterson and Bennett present "the music festival" as an example of translocal scenes. Lastly, virtual scenes refer to connected music scenes which come together via the Internet. They share fanzines, albums and other media by using technology. In this context, Thomas Solomon argues that Turkish hip-hop "seems to have aspects of all three of the types of music scenes Peterson and Bennett identify (Solomon, 2009, p. 316)”. Nevertheless, for the Turkish-language rap scene in the Netherlands as a local scene, it is hard to claim that aspects of transnational and virtual scenes could be found in fact. For instance, it is not possible to mention any national or international music festivals organized or events in the Netherlands that Dutch-Turkish rappers are actively involved. Virtually, it can be hard to say that there are few rappers who have contact with their counterparts outside the Netherlands in the different countries actively as well. For example, I experienced serious difficulties to find out or to reach Dutch-Turkish rappers before beginning to carry out the fieldwork, since unlike their counterparts in Germany, it is not easy to reach DutchTurkish rappers by using Internet or other sources such as fanzines, magazines, etc. I used many different keywords (such as Dutch-Turkish rap scene, Turkish rap in the Netherlands, etc.) for different search engines, yet I was able to few artists and news about the scene. After starting to my fieldwork, many of rappers shared similar thoughts and conditions about their low level contacts with their counterparts from different countries. It seems to be somehow not tightly connected to other rap scenes in different geographies, such as Germany or Turkey, but rather it is a relatively closed network in itself, even though of course there are some exceptional rappers such as MT, who featured with very popular Belgium-born, Turkish, female singer, Hadise, who represented Turkey in the Eurovision Song Contest 2009 by the song "Düm Tek Tek"; or Al-J, who worked together with the prominent Turkish rapper, Ceza, from Istanbul.

On the other hand, when we look at German-Turkish rappers, it may be said that they do have very active interaction and collaboration with their counterparts in Turkey, such as the collaboration among very prominent rapper, Ceza, from Turkey or Killa Hakan, Eko-Fresh, Kool Savaş from Germany. Moreover, it is possible to talk about music festivals and carnivals in Germany, organized regularly, for instance Splash!, first held in 1998, that one of Europe's largest hip-hop and reggae events, in which Turkish-German rappers are actively involved. On the one hand, there are some prominent Turkish-German rappers who gain great commercial success in the host country, for example, Karakan, Kool Savaş, Eko Fresh, etc. For example, Cartel's album (1995) sold about one million copies in Germany and Turkey. Beginning in 2002, Kool Savaş, for instance, released his first solo album titled "Der beste Tag meines Lebens". It sold about 90.000 copies (vvveuropeanhiphop, 2014). However, during my stay in the Netherlands, it could not be mentioned any commercial Dutch-Turkish rap album sold in the music markets in all around the country. Piece of works by rappers were dominantly shared by hand as CDR. There were few rappers who had MySpace pages, for example MT mentioned above.

Hip-hop culture among Dutch-Turks is less "coherent" in comparison with its counterpart in Germany not just because of the commercially unsuccessful, but also while it is still possible to talk about a visible publicity of Turkish hip-hop in Germany provided with festivals, concerts, radio and newspaper announcements so on so forth (Soysal 1999), the Turkish-Dutch scene has few concerts, festival or events, since there are not enough actively involved listener-fans in the Netherlands to support such festivals or concerts. For the Turkish-language rap scene in the Netherlands, it is hard to claim that two types of music scenes could in fact be found. It seems to 
be somehow not tightly connected to other rap scenes in different geographies, such as Germany or Turkey, but rather it is a relatively closed network in itself, even though of course there are some exceptional rappers such as MT (born in Turkey, migrated to the Netherlands when he was 16), who featured with very popular Belgiumborn, Turkish, female singer, Hadise, also known from her performance in the Eurovision Contest 2009; or Al-J, who cooperated with prominent Turkish rapper, Ceza, from Istanbul just for one song . Ceza and Killa Hakan have had a tremendous impact on the Turkish-speaking rap scene. It is hard to say that prominent Dutch-Turkish rapper Şener-E or any Turkish rappers gained publicly visibility or commercial success in spite of high density of the Turkish population in the Netherlands.

\section{Conclusion}

Over time, rap gained widespread acceptance in Turkey and the Netherlands by the late 1990s. In both Germany and the Netherlands, Turkish rappers use music to reflect their own personal thoughts and the difficulties they experience in the host countries. However, linguistic differences and "brutal" attacks taking place in Germany seem to have paved the way for the appearance of much more "developed" or "hard core" (see Maxwell, 2003) rap scene. Unlike Germany, the Turkish-speaking rap scene of the Netherlands has gained its own particularities not from "a violent" social environment, but contrarily from a much more peaceful and multicultural one. In the Dutch case, there is a more welcoming (or at least tolerant) policy toward cultural differences and the presence of different languages, in contrast to the German approach. But the ghettoization of Turks in Germany resulted in more cultural coherence among them, including a higher level of proficiency in the Turkish language, while the tolerant multicultural approach in the Netherlands actually led to more assimilation and less proficiency in the language. In this sense, hip-hop culture has not been able to become a coherent scene in the Netherlands as it has, to some degree, in Germany. Apparently, socio-political, musical and linguistic issues seem to make such distinctions between the two respective countries much more visible. In this context, my main challenge with this topic of study was whether I should evaluate the Dutch case as a scene having similar characteristics, such as huge fan support, well-organized festivals, new sub-genres, i.e.

It seems that the socio-political differentiations between the two countries have had a deep impact on the development of rap music. For this reason I have stressed multiculturalism and the policies concerning foreigners practiced in both countries. The socio-cultural and policies practiced in both countries have progressed to the point that distinctions between the rap scenes in both have become much more visible. In the past works of rappers, Cartel's influence was much more apparent, but this is no longer always the case. It can easily be observed that rappers use music in different ways against racism, xenophobia, or state policies and politics that they are subjected to. Nikos Papastergiadis refers to early sociological accounts in which "[M]igrants and racial minorities have been the subject of many empirical studies which have demonstrated the injustices, hypocrisy and negligence of the welfare system" (Papastergiadis, 1998, p. 35). According to him, such sociological accounts are concerned with "the dysfunctions of the state" (ibid). It seems that such issues are not one-dimensional sociological issues connected by merely "the dysfunctions of the state", but rather they include many variables such as culture, historical background, media, social life, etc.

Turkish people's use of rap music more effectively and as a means of reacting against xenophobia, racism and even the racist attacks that they are subjected to, does not appear as merely a coincidence. As I expressed earlier, hip-hop culture in the Netherlands is less prevalent than in Germany. One of the reasons for this, besides the inclusive policies of the Dutch state, was the lack of racist attacks against people in the Netherlands until the 
beginning of 2000s. The common perception of rappers I interviewed was that they did not feel to be threatened directly by their host society. Particularly the equality and difference from the host-society makes this issue more complicated. But the fact that the legal and cultural structures of the country directly influence the lives of its foreigners is also a crucial issue. 


\section{Kaynaklar/References}

Appadurai, A. (1983). Modernity at Large: Cultural Dimensions of Globalization. London: University of Minnesota Press.

Bennett, A. (2000). Popular Music and Youth Culture: Music, Identity and Place. New York: St. Martin's Press.

Çağlar, A. (1998). Popular Culture, Marginality and Institutional Incorporation. Cultural Dynamics 10.3, $243-61$.

de Wit, T. D, and Ruud Koopmans. (2005). The Integration of Ethnic Minorities into Political Culture: The Netherlands, Germany and Great Britain Compared. Acta Politica 40.1, 50-73.

Deleuze, G. and Guattari, Félix. (1990). Anti-Oedipus: Capitalism and Schizophrenia. Minneapolis: University of Minnesota Press.

“Der beste Tag meines Lebens” Retrieved in 22 May 2014, from http://vvveuropeanhiphop.eu/kool-savas.

Diessel, C. (2001). Bridging East and West on the 'Orient Express': Oriental Hip-Hop in the Turkish Diaspora of Berlin. Journal of Popular Music Studies 13.2, 165-87.

Doomernik, J. (2009). The Effectiveness of Integration Policies Towards Immigrants and Their Descendants in France, Germany and the Netherlands. International Migration Papers 27.

Eldering, L. (1997). Ethnic Minority Students in the Netherlands from a Cultural-Ecological Perspective. Anthropology and Education Quarterly 28.3, 330-50.

Elflein, D. (1998). From Krauts with Attitudes to Turks with Attitudes: Some Aspects of Hip-Hop History in Germany. Popular Music 17.3, 255-265.

el-Ojeili, C. and Hayden, Patrick. (2006). Critical Theories of Globalization. New York: Palgrave Macmillan.

Featherstone, M. (1997). Undoing Culture. London: SAGE.

Frith, S. (2004). "What is Bad Music?" In Bad Music: The Music We Love to Hate edited by Christopher J. Washburne and Maiken Derno, 15-39. New York: Routledge.

Greve, M. (2006). Almanya'da Hayali Türkiye’nin Müziği [Imaginative Music of Turkey in Germany]. İstanbul: Bilgi Üniversitesi Yayınları.

Kaya, A. (1998). Multicultural Clientelism and Alevi Resurgence in the Turkish Diaspora: Berlin Alevis. New Perpectives on Turkey 18, 23-51.

Kaya, A. (2001). Sicher in Kreuzberg: Constructing Diasporas: Turkish Hip-Hop Youth in Berlin. Verlag: Transcript.

Kearney, M. (1995). The Local and the Global: The Anthropology of Globalization and Transnationalism. Annual Review of Anthropology 24, 547-65.

Koopmans, R. and Paul Statham. (2001). How National Citizenship Shapes Transnationalism: A Comparative Analysis of Migrant, Claims-Making in Germany, Great Britain and the Netherlands. Revue Eurohernne des Migrations Internationales 17, 63-100.

Maxwell, I. (2003). Phat Beats, Dope Rhymes. Middletown: Wesleyan University Press.

Osmanoğlu, Y. K. (2009). Yaban [The Stranger], İstanbul: İletişim.

Papastergiadis, N. (1998). Dialogues in the Diasporas: Essays and Conversations on Cultural Identity. London: Rivers Oram Press.

Penninx, R. (1996). Immigration, Minorities Policy and Multiculturalism in Dutch Society since 1960. In The Challenge of Diversity: Integration \& Pluralism in Societies of Immigration, edited by Rainer Bauböck and Agnes Heller, 187-206. Aldershot: Avebury.

Peterson, R. and Andy Bennett. (2004). "Introducing Music Scenes.” In Music Scenes: Local, Translocal and Virtual edited by Andy Bennett and Richard Petertson, 1-15. Nashville: Vanderbilt University Press.

Ritzer, G. (2003). Rethinking Globalization: Glocalization/Grobalization and Something/Nothing. Sociological Theory 21(3), 193-209.

Robertson, R. (1995). “Glocalization: Time-Space and Homogeneity-Heterogeneity.” In Global Modernities, edited by Mike Featherstone, Scott Lash and Roland Robertson, 25-44. London: Sage. 
Robins, K. and David Morley. (1996). “Almanc1, Yabanc1.” Cultural Studies 10.2, 248-54.

Saharso, S. (2007). Headscarves: A Comparison of Public Thought and Public Policy in Germany and the Netherlands. Critical Review of International Social and Political Philosophy 10.4, 513-30.

Simmel, G. (1950). The Sociology of Georg Simmel. New York: Free Press.

Solomon, T. (2007). Whose Diaspora? Hybrid identities in 'Turkish Rap' in Germany. Paper for the 14th Nordic Migration Researchers' Conference: Bergen, November 14-16.

Solomon, T. (2009). Berlin, Frankfurt, Istanbul: Turkish Hip-Hop in Motion. European Journal of Cultural Studies 3.12, 305-27.

Soysal, L. (1999). Projects of Culture: An Ethnographic Episode in the Life of Migrant Youth in Berlin [Unpublished Doctoral thesis submitted to Anthropology and Middle Eastern Studies, Harward University], Ann Arbor.

Turino, T. (2003). Are We Global Yet? Globalist Discourse, Cultural Formation and the Study of Zimbabwean Popular Music." British Journal of Ethnomusicology 12.2, 51-79.

Verkuyten, M. and Ali Aslan Yıldız. (2007). "National (Dis)Identification and Ethnic and Religious Identity: A Study among Turkish-Dutch Muslims." Personality Social Psychology Bulletin 33, 1448-62.

Vink, M. P. (2007). Dutch 'Multiculturalism' Beyond the Pillarisation Myth. Political Studies Review 5, 337-50.

\section{Discography}

Arka Sokak. (2004). "Patlamaya Hazır Olan Dünya.” Underground Release.

Ceza and Killa Hakan. (2008). Bomba Plak (CD-R). İstanbul: Esen Elektronik. 
